\title{
Media preferences, micro-morphometric analysis, and cardinal growth temperature determination for Phytophthora infestans sensu lato isolated from different hosts in Colombia
}

\author{
S. Gómez-González ${ }^{a}$ (D), D. Castañeda-Sánchez ${ }^{a}$ (D) and J. Morales-Osorio ${ }^{a *}$ (D) \\ ${ }^{a}$ Departamento de Ciencias Agronómicas, Facultad de Ciencias Agrarias, Universidad Nacional de Colombia, \\ Calle 59A No. 63-20, Núcleo El Volador, Bloque 11, Oficina 117-13, Medellín, Colombia \\ *e-mail: jgmoraleso@unal.edu.co
}

Received: July 3, 2018 - Accepted: September 17, 2018 - Distributed: February 28, 2020

(With 4 figures)

\begin{abstract}
During the last years Phytophthora infestans sensu lato (Mont. De Bary) has caused epidemics in Colombia in Andean fruit crops such as Solanum quitoense and Solanum betaceum. Establishment of new or modified experimental procedures to study this pathogen is a mandatory subject for scientists. Twelve isolates of Phytophthora spp. obtained from six different Solanum hosts in Colombia were used to evaluate the effect of five different solid media for growth and ability to produce sporangia and liberate zoospores. Determination of the best media culture and optimal growth temperature were necessary to perform measurements and correlate the provenance of isolates with phenotypic traits. Modifications were made to use ingredients available in local markets on the following media: lime bean agar (LBA), Tree tomato or tree tomato agar (TA), carrot agar (AZ), Rye A modified agar and 32\% non-clarified V8 agar. Cardinal temperature determination was performed at $10,15,20$, and $25^{\circ} \mathrm{C}$. Morphometric traits were measured once the optimal media culture and temperature were defined. Correlation analysis showed that there is a relationship between the host and isolate's preferences for media culture and optimal growth temperature. In addition, the production of characteristic sporangia, sporangiophore and mycelia was related with the media type used and host from which the isolate was collected. In this work useful information was provided to make studies about the biology and development of isolates gathered from cultivated and wild non-traditional hosts.
\end{abstract}

Keywords: late blight pathogen, Solanum hosts, zoospores, sporangia, optimal growth media.

\section{Preferências de mídia, análise micro-morfométricos e determinação da temperature cardeal de crescimento para Phytophthora infestans sensu lato isolada de diferentes hospedeiros na Colômbia}

\begin{abstract}
Resumo
Durante os últimos anos Phytophthora infestans sensu lato causou epidemias na Colômbia em lavouras de frutos andinos, como Solanum quitoense e Solanum betaceum. Estabelecimento de procedimentos experimentais novos ou modificados para estudar este patógeno é um assunto obrigatório para os cientistas. Doze isolados de Phytophthora spp. obtidos de seis diferentes hosts Solanum na Colômbia foram usados para avaliar o efeito de cinco diferentes mídias sólidas para o crescimento e a capacidade de produzir esporângios e libertar zoósporos. Determinação da melhor cultura de mídia e temperatura de crescimento ideal foram necessárias para realizar medições e correlacionar a proveniência de isolados com traços fenotípica. Foram feitas modificações para usar os ingredientes disponíveis nos mercados locais nos seguintes meios: ágar do feijão de cal (LBA), tomate da árvore ou ágar do tomate da árvore (TA), ágar da cenoura (AZ), centeio um ágar modificado e 32\% de ágar-V8 não-esclarecido. A determinação da temperatura Cardeal foi realizada em $10,15,20$ e $25^{\circ} \mathrm{C}$. Traços morfométricos foram medidos uma vez que a cultura de mídia ideal e temperatura foram definidos. Análise de correlação mostrou que há uma relação entre o hospedeiro e isolar as preferências para a cultura de mídia e temperatura de crescimento ideal. Além disso, a produção de esporângios característica, esporangióforo e mycelia foi relacionada com o tipo de mídia utilizado e hospedeiros a partir do qual o isolado foi coletado. Neste trabalho foram fornecidas informações úteis para fazer estudos sobre a biologia e o desenvolvimento de isolados recolhidos de hospedeiros não-tradicionais cultivados e selvagens.
\end{abstract}

Palavras-chave: míldio da batata, hospedeiros Solanum, zoósporos, esporângios, mídia de crescimento ideal. 


\section{Introduction}

Phytophthora infestans sensu lato (Mont. De Bary) is a devastating oomycete pathogen causing the late blight disease in several plant species mainly in the Solanaceae botanical family (Forbes et al., 2013; Cárdenas et al., 2011; Silva et al., 2009). Potato (Solanum tuberosum L.) and tomato (S. lycopersicum L.) are the most important crops affected by this microorganism at the worldwide level (Grünwald and Flier, 2005). In South America, including Colombia there are other crops affected by this pathogen such as lulo or naranjilla (S. quitoense Lam.), tree tomato or tamarillo ( $S$. betaceum Cav.), pear melon (S. muricatum Ait.) and other crop and wild species (Forbes et al., 2013; Zapata and Bernal, 2012). These Andean fruit crops have good potential for the internal and for the export markets and are very important from a socio-economic point view because they are grown mainly by small farm-holders and they are included in the list to replace illicit crops in the affected areas (Gutiérrez, 2009). In tree tomato and lulo, the disease was unknown until recently, farmers did not recognize symptoms or confused them with other pathologies like anthracnosis caused by Colletotrichum sp. (Corda) or the chlorotic spot caused by Cladosporium sp. (Link) Therefore, this disease was controlled mistakenly increasing costs, contaminating the environment and affecting health (Pardo-De La Hoz et al., 2016; Afanador-Kafuri et al., 2003).

Basic information about $P$. infestans in Andean crops and wild species is scarce (Forbes et al., 2013). Recently, from diseased solanaceous plants showing similar symptoms a new species was isolated and named Phytophthora andina (Adler and Flier). This report was criticized and still is under debate, for this reason Phytophthora infestans sensu lato is used in the literature as the causal agent of the late blight symptoms in plant hosts. P. infestans sensu lato is a versatile pathogen which can adapt rapidly to new environments, control by chemical products and new hosts such as new crop varieties. In South America including Colombia, cultivated and wild plant hosts grow on the same life zones, usually at an altitude between 1800-2800 masl (meters above the sea level) and are present all year round creating permanently favourable conditions for pathogen development. For these reasons, late blight control is very difficult and basic research mainly in the Andes of South America is urgently needed.

Environmental conditions such as temperature, humidity, nutrient preferences and others, are major abiotic factors impacting all levels of biological functions of plant pathogens from molecules to ecosystems and they influence all ecological communities and interactions. In host-pathogen interactions, they can strongly affect epidemic development modulating key stages of the pathogen life cycle such as sporangia germination, zoopore, cyst formation and germ tube elongation (Mariette et al., 2016). Due to the large diversity of $P$. infestans sensu lato genotypes involved in the epidemics around the world in the last decades, it is important to develop protocols and methodologies to study specific requirements of media, temperature and other growth factors, for the different isolates obtained from a wide range of hosts and geographical origins as usually occurs in Colombia (Goss et al., 2014; Lamour, 2013; Erwin and Ribeiro, 1996).

\section{Material and Methods}

\subsection{Isolates collection and maintenance}

Isolates were collected during the years 2012 and 2014 from different regions in the Andean range in Colombia, South America, where crop and wild hosts grow up. Altitude, host, georeferenced localization and date of collection of each isolate evaluated were registered (Table 1). Samples were put inside labelled paper bags and kept in polystyrene containers with ice until they were processed in the laboratory. The plant tissue was washed thoroughly using tap water, then was dried in a paper towel and incubated in a humid chamber for 24 to 48 hours (controlled growing cabinet Sanyo ${ }^{\circledR}$ ) in darkness and at a temperature between 18 to $20{ }^{\circ} \mathrm{C}$, to stimulate sporulation. Once profuse sporulation occurred, sporangia were collected on a $10-\mu \mathrm{m}$ filter and rinsed with sterile distilled water. The obtained suspension was visualized under the light microscope at $400 \mathrm{x}$ to verify structures of Phytophthora infestans sensu lato and concentration was adjusted to $2 \times 10^{4}$ sporangia $\mathrm{mL}^{-1}$ in sterile distilled water. Two droplets of $20 \mathrm{uL}$ of the sporangia suspension were deposited on susceptible potato slices cv. Careta, cv. Sabanera or cv. Tuquerreña (S. tuberosum subsp. andigena), or on healthy leaves of $S$. betaceum washed thoroughly with sterile distilled water for the isolates collected from tree tomato. Inoculated isolates were then incubated in the controlled growing chamber, in sealed plastic containers with free water in the bottom to guarantee high humidity, for five to seven days at 18 to $20^{\circ} \mathrm{C}$.

Depending on the sporulation intensity, the isolate was transferred to semi-selective media culture or sporangia were collected again and the process was repeated until enough sporangia were obtained to be transferred to semi-selective media. For samples collected from wild Solanum plants (Solanum sp. (L.) and S. caripense (Dunal)), isolates were kept on detached leaves of the same host from which they were collected, due to the difficulty to transfer these isolates to synthetic media culture, incubated under the same conditions described and transferred to fresh leaves every 5 to 8 days. For long term storage, sporangia from isolates were frozen in liquid nitrogen as suggested by Zapata and Bernal (2012).

\subsection{Mating type}

The first approach to determine the mating type was to pair our set of isolates with a known A1 mating type reference isolate in media culture Rye A modified (with ground grain instead of soaked grain). Sixty grams of rye flour were dissolved in $1 \mathrm{~L}$ of distilled water, $18 \mathrm{~g}$ of sugar added and $20 \mathrm{~g}$ of bacteriological agar amended with $\beta$-sitosterol (25 mg/L). Plates were placed in an incubator 


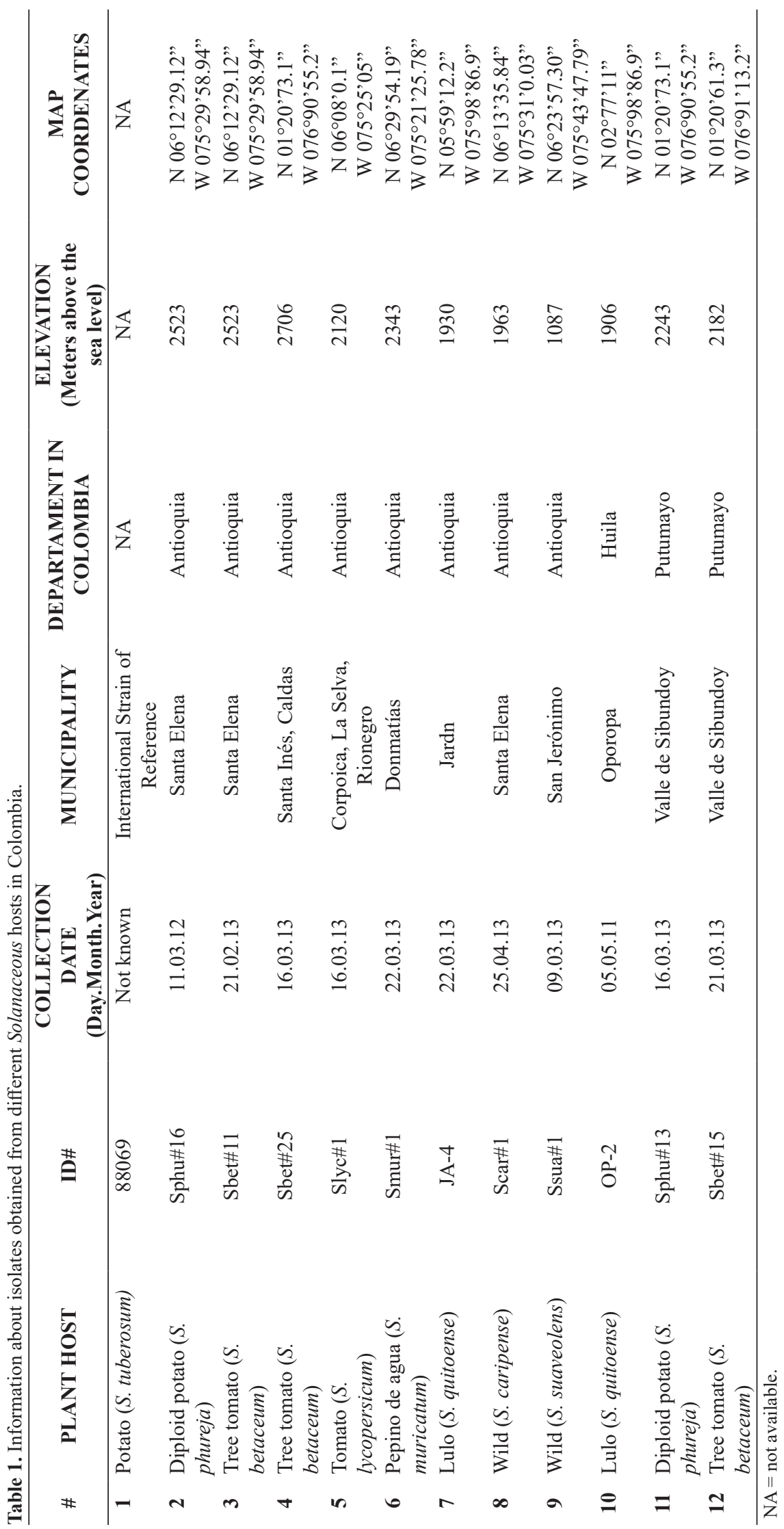


at $15{ }^{\circ} \mathrm{C}$ in the dark and examined for the presence of oospores after 4 weeks. The second approach was to test for a marker linked to the mating-type locus using a reported polymerase chain reaction (PCR)-based assay (Pérez et al., 2001; Judelson, 1996). DNA from freeze-dried mycelia obtained from the growth in pea broth was extracted and purified using the DNeasy ${ }^{\circledR}$ plant mini kit, quantified in Nanodrop ${ }^{\circledR}$, visualized in an agarose gel electrophoresis and used as a template in a $25 \mathrm{uL}$ PCR reaction. Primers used were S1A (5'-AGGATTTCAACAA) and S1B (5'-TGCTTCCTAAGG) described by Judelson (1996). These primers amplify a fragment of DNA of approximately 1,250 bp corresponding to locus $\mathrm{S} 1$, which is linked to the A1-determining allele of the mating-type locus.

\subsection{Media preference test}

Some of the original recipes were modified, Rye A, instead of using the fermented grain extract, it was used rye flour $(60 \mathrm{~g} / \mathrm{L})$ combined with sucrose $(18 \mathrm{~g} / \mathrm{L})$ and bacteriological agar (20 g/L). Non-clarified V8 juice agar adjusted to $32 \%$ and combined with $\mathrm{CaCO}_{3}(0.5 \mathrm{~g} / \mathrm{L})$, sucrose $(18 \mathrm{~g} / \mathrm{L})$ and bacteriological agar $(20 \mathrm{~g} / \mathrm{L})$ and $\mathrm{pH}$ adjusted to 6.2 with $\mathrm{NaOH} 1 \mathrm{~N}$ was used. For the carrot agar (AZ) 100g of carrot pieces were boiled in one litre of distilled water during 30 minutes. After filtering through four layers of cheese cloth it was mixed with $25 \mathrm{~g} / \mathrm{L}$ of agar. No sugar was added. The Tree tomato Agar (TA) was modified from the reported by Revelo et al. (2011). $125 \mathrm{~g}$ of tree tomato pulp was blended in $500 \mathrm{~mL}$ of distilled water then filtered through four layers of cheese cloth and $250 \mathrm{~mL}$ were mixed with $100 \mathrm{~mL}$ of green pea broth $(75 \mathrm{~g}$ boiled peas for $30 \mathrm{~min}$ in $300 \mathrm{~mL}$ of water), then combined with $\mathrm{CaCO}_{3}(0.5 \mathrm{~g} / \mathrm{L})$, sucrose $(18 \mathrm{~g} / \mathrm{L})$ and bacteriological agar $(20 \mathrm{~g} / \mathrm{L}), \mathrm{pH}$ adjusted to 6.2 with $\mathrm{NaOH} 1 \mathrm{~N}$. Colony growth rate was determined by taking agar plugs $(10 \mathrm{~mm}$ in diameter) from the margins of 10 to 12 days old Rye A cultures and transferred to two plates of each media. Isolates were then incubated in the growing chamber at $18-20{ }^{\circ} \mathrm{C}$ in darkness for 15 days. Every two days from the fifth day until the fifteenth day two perpendicular measurements of each colony were taken. On the last day of incubation, the Petri plate was flooded with $10 \mathrm{~mL}$ of sterile distilled water and sporangia concentration was counted using a Neubauer's chamber. This assay was repeated two times.

\subsection{Cardinal temperature test}

Vegetative growth in a range of temperature from 10 to $25^{\circ} \mathrm{C}$ at intervals of $5{ }^{\circ} \mathrm{C}$ was evaluated to find out which was the optimal in order to favour the production of microscopic structures of each isolate. Agar disks (10 mm) from the growing margins of cultures of each isolate were transferred to Rye A agar and were incubated in darkness. There were two replicates per isolate per each temperature in each experiment, and experiments were replicated three times. The colony diameter was measured at 15 days post-inoculation in two orthogonal directions, and the average for each temperature was calculated.

\subsection{Micro-morphometric analysis}

After 15 days growing under optimal conditions of media culture and temperature, sporangia of two plates were collected washing the surface of each plate with $10 \mathrm{~mL}$ of sterile distilled water. The length and width (in micrometers) of 50 randomly selected sporangia of each isolate were measured at $200 \times$ using light microscopy and video image analysis (Nikon Microscope Camera DS-Fi3) and used to calculate the sporangia length/width ratios. Pedicel length was measured with an ocular micrometer. Isolates were compared for sporangial length and width, pedicel length, type of papilla, pedicel attachment, caducity and hypha thickness.

\subsection{Zoospore liberation}

Sporangia suspensions were obtained as described previously and used to evaluate the ability of each isolate to liberate zoospores at $4{ }^{\circ} \mathrm{C}$. Aliquots from the sporangia suspension incubated at $4{ }^{\circ} \mathrm{C}$ were taken every thirty minutes and mounted in the Neubauer's chamber to count the number of free zoospores released by each isolate. The measurement was repeated twice and two measures were recorded per isolate at every time.

\subsection{Statistical analysis}

The best conditions to grow, produce and deliver dispersal and reproductive structures of $P$. infestans sensu lato were established by stages. Differences between each factor (isolate, media culture, temperature and time) were determined by Analysis of variance ANOVA ( $95 \%$ probability). For those cases where significant differences $(\mathrm{P}<0.05)$ were detected, the LSD (Least significant differences) test was used to compare means. To graph the interactions, a conglomerates grouping methodology was used to define the factors (origin, hosts) that permit to categorize the 11 isolates tested. This method correlates individuals according to their similarity based on characteristics that describe them in a similar way.

\section{Results}

During the process of isolation of $P$. infestans it was observed that some isolates spend more time growing than others so we decided to evaluate different types of media culture reported in the literature to see whether this difference was due to specific nutrient requirements of each isolate. We found that isolates from tree tomato were difficult to grow on Rye agar, used as the standard media for P. infestans around the world. Evenmore, we observed that isolates collected from potato leaves do not grow well in tree tomato leaves, suggesting requirement of nutrients and host specific components (Table 2).

\subsection{Mating type}

Sexual structures such as oospores, oogonium or antheridium were not observed after the incubation with the reference strain A1. PCR results showed the expected amplicon of about $1250 \mathrm{pb}$ present in all isolates evidencing the presence of the locus $\mathrm{S} 1$ related with the mating type A1 only (Data not shown). 
Table 2. Growth of each isolate in different media. Pictures were taken after 15 days of incubation at $18{ }^{\circ} \mathrm{C}$. Three representative isolates were selected for these pictures.

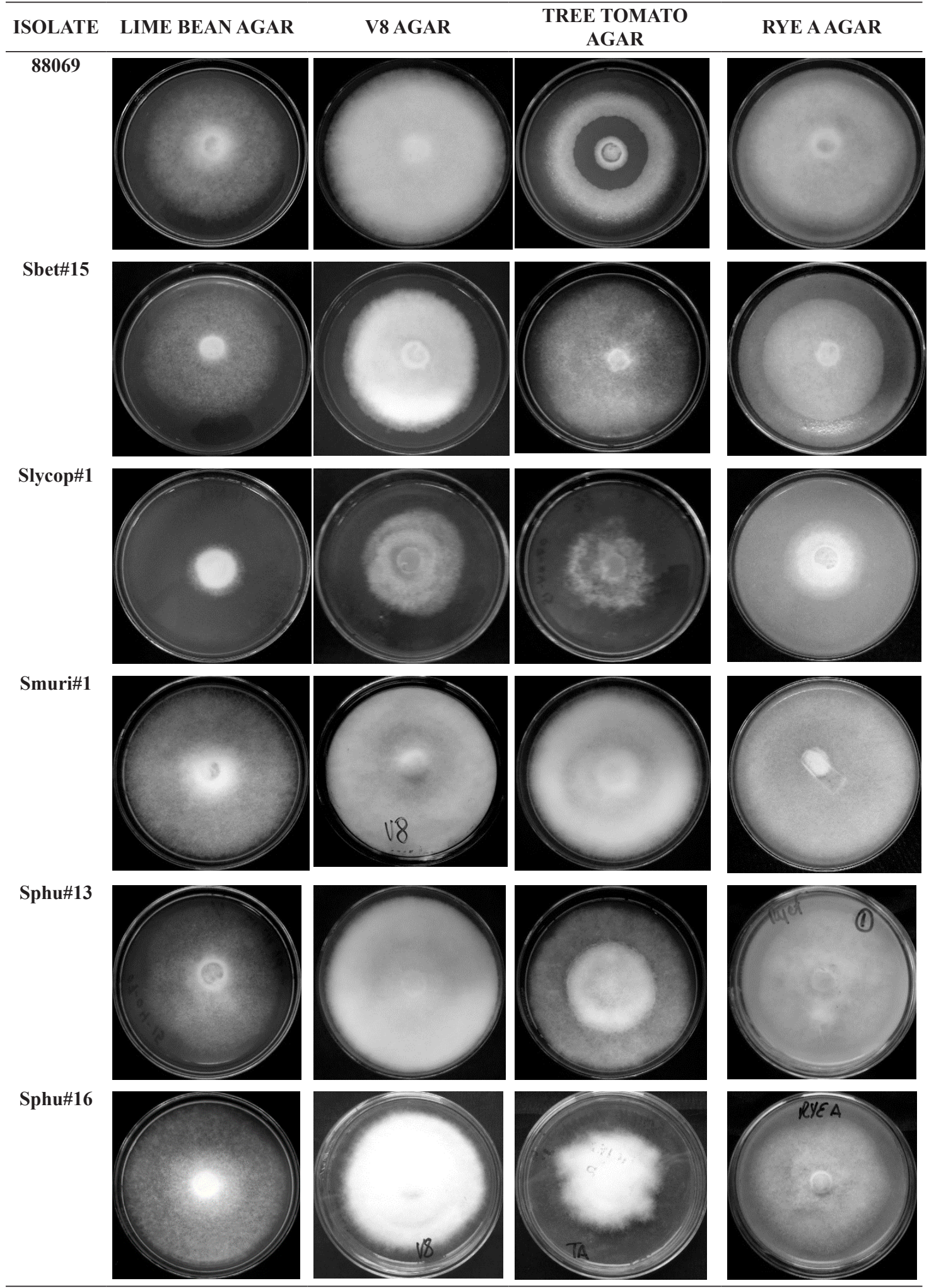


Table 2. Continued...

\begin{tabular}{|c|c|c|c|c|}
\hline ISOLATE & LIME BEAN AGAR & V8 AGAR & $\begin{array}{c}\text { TREE TOMATO } \\
\text { AGAR }\end{array}$ & RYE A AGAR \\
\hline Sbet\#11 & & & & \\
\hline Sbet\#25 & & & & \\
\hline JA-4 & & & & \\
\hline OP-2 & & & & \\
\hline
\end{tabular}

\subsection{Media preferences test}

All isolates tested exhibited similar circular homogenous growth pattern at $18{ }^{\circ} \mathrm{C}$ on every medium (Table 2). However, they differed significantly in their growth rate on each media $(\mathrm{P}<2 \mathrm{e}-16)$. Furthermore, it was found that Tree tomato (TA) and V8 were the most convenient media for growing all the isolates evaluated, followed by the Rye A modified, then by Carrot Agar (AZ) and finally the Lima bean Agar (LBA). Colonies showed sparse aerial mycelia and grew at the greatest rates on TA, especially the tree tomato isolates (Sbet\#11, Sbet\#15, Sbet\#25). All isolates produced hispid aerial mycelia on V8-(32\%) agar and on tree tomato agar. On lime bean agar (LBA), Rye A and Carrot agar (AZ), all isolates exhibited superficial mycelia. The colony pattern on $\mathrm{AZ}$ was radiate with a smooth edge. Irregular growth pattern was observed on tree tomato agar for isolates Slycop\#1, Sphu\#13 and Sbet\#25. Isolates JA-4 and OP-2 collected from lulo (S. quitoense) needed more time than other isolates ( 30 days) to cover $80 \%$ of the Petri plate in Rye A, LMA and TA. Carrot agar (AZ) and V8 agar were unable to support the growth of these isolates.

The paired analysis showed that the isolate 88069 grew faster than other isolates in all media tested with a mean of $49.976 \mathrm{~mm}$. In contrast, JA-4 from lulo (S. quitoense) was the slowest isolate with a media of $6.942 \mathrm{~mm}$ in all media after 15 days of incubation at $18^{\circ} \mathrm{C}$. The media culture with the best conditions for the growth of all isolates evaluated after 15 days of incubation at $18{ }^{\circ} \mathrm{C}$ was the tree tomato agar with a mean $=40.6285 \mathrm{~mm}$ and Lima Bean Agar (LBA) (media $=26.271 \mathrm{~mm}$ ) was the less growth-promoting media culture. After 15 days of incubation, isolates grew on average $54.1108 \mathrm{~mm}$ in all media evaluated. The interaction between isolate and media culture evidenced by the LSD test showed that TA medium ( mean $=55.617 \mathrm{~mm}$ ) and Rye A agar medium (mean=54.142 $\mathrm{mm}$ ) were the best media for isolate 88069 reaching a maximum of $85 \%$ of growth 
in 15 days post-inoculation. Isolate JA-4 had the slowest growth rate in all media culture needing 30 days to cover $85 \%$ of the Petri plate in the best growing medium TA (media=14.531 mm).

The hierarchical cluster analysis grouped the isolates growing in different media cultures based on their geographical origin and the host from they were collected. The first group included two isolates from the host S. betaceum, Sbet\#11 and S.bet\#25 collected in Antioquia, Colombia. The second group was composed by isolates: Sphu\#16, JA 4, Smur\#1 and Slyc\#1, all of them from four different Solanaceous hosts collected in Antioquia, Colombia: S. phureja, S. quitoense, S. muricatum and $S$. lycopersicum respectively. The other two isolates from $S$. betaceum, Sbet\#15 and Sbet\#16, were included in the fourth group together with the Sphu\#13 from potato. These three isolates were collected in Valle de Sibundoy, Putumayo, Colombia (Figure 1).

\subsection{Sporangia production in media culture}

There were significant differences in the number of sporangia produced by each isolate incubated at $18^{\circ} \mathrm{C}$ after 15 days post-inoculation. Values varied from 5.417 to 100.883 sporangia per millilitre, being the isolate Sbet\#25 from tree tomato collected in Antioquia growing on TA media the most productive and the reference isolate

\section{Cluster dendogram with p-values (\%)}

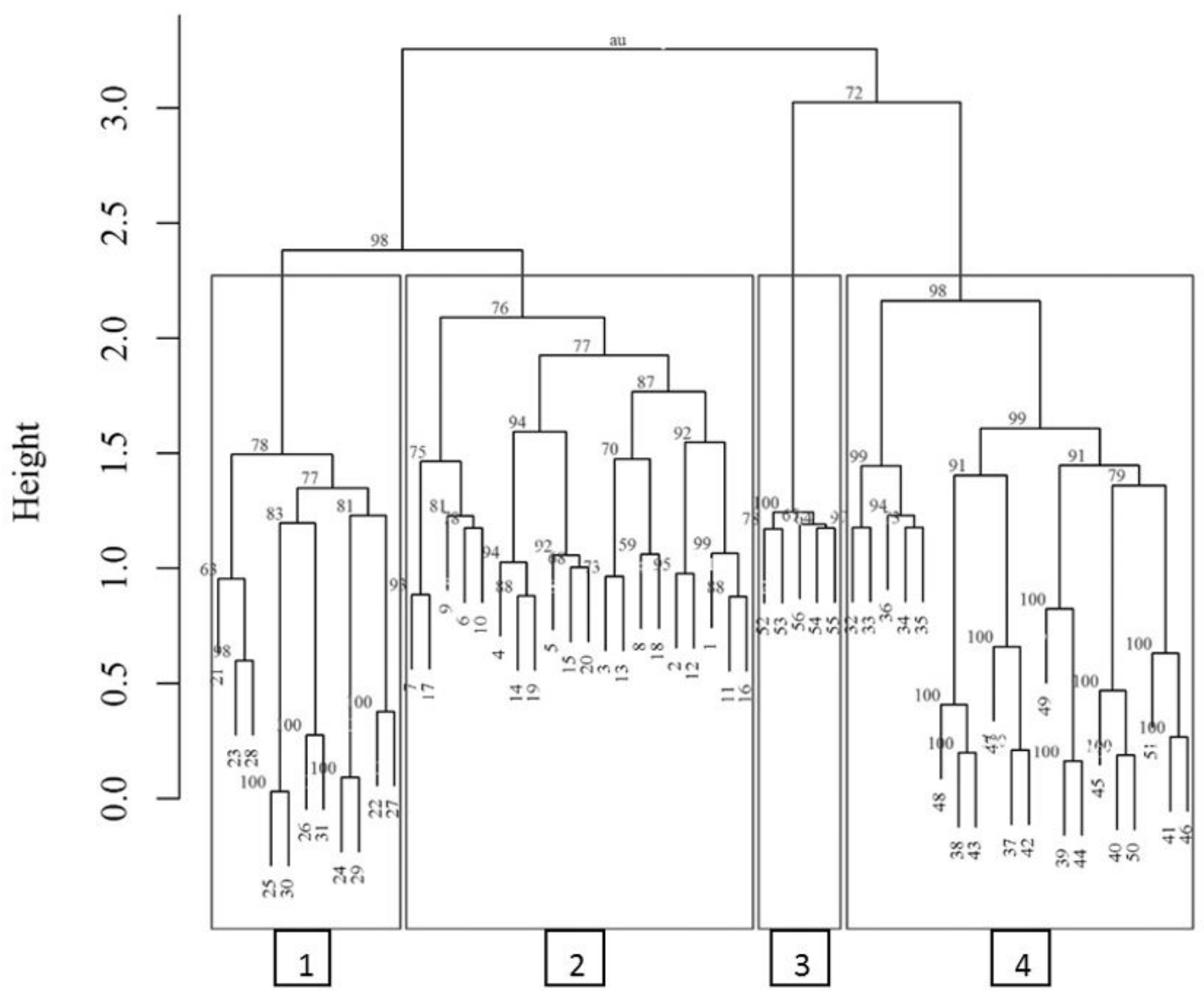

\section{Distance: euclidean \\ Cluster method: complete}

Figure 1. Cluster dendogram grouping isolates based on growth rate in different media cultures. Group 1: Sbet\#11, 21-26 and Sbet\#25, 27-31; Group 2: Sphu\#16, 1-5; JA_4, 6-10; Smur\#1, 11-15 and Slyc\#1, 16-20; Group 3: 88069, 52-56; Group 4: Sphu\#13, 32-36; Sbet\#15, 37-41 and Sbet\#16, 42-46. 
88069 growing on AZ media the less productive. Modified Rye A was the media culture where most of the isolates produced the highest amount of sporangia after 15 days post-inoculation $($ mean $=58.546$ sporangia $/ \mathrm{mL}$ ) and $32 \%$-non clarified V8 agar was the media with the lowest mean of sporangia concentration produced by the isolates evaluated under the same conditions (17.027 sporangia/mL) (Figure 2). No significant differences were identified for sporangia production between Rye A and Tree tomato Agar (TA) and between Lima bean agar (LBA) and Carrot Agar (AZ) media after 15 days post-inoculation. The LSD test showed that the isolate Sbet\#25 from $S$. betaceum gathered from Antioquia, Colombia and growing on tree tomato Agar (TA) media exhibited the highest sporangia concentration $($ mean $=256.944$ sporangia $/ \mathrm{mL})$ and
Sbet\#11 growing in Rye A showed the lowest sporangia production (mean=1.999 sporangia/mL).

The hierarchical cluster constructed using the variable sporangia production by each isolate in all media culture evaluated after 15 days post-inoculation at $18^{\circ} \mathrm{C}$ produced three groups and an outlier member. The first group was composed by all isolates growing on Rye A media modified which is the media where the production of sporangia was the highest as mentioned above. The second group contained all the isolates growing on media V8-32\%-non-clarified where the sporangia production was the lowest. Finally, the biggest group contained three small sub-groups conformed each by isolates growing on AZ, LBA and TA. Isolate Sbet\#25, with the highest sporangia production in TA media was the outlier from the group.
AZ

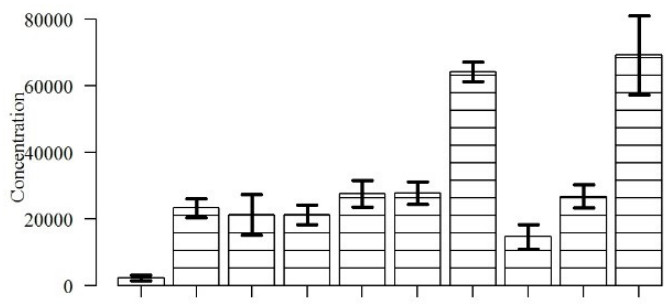

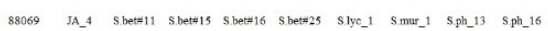

Isolate

Rye_A

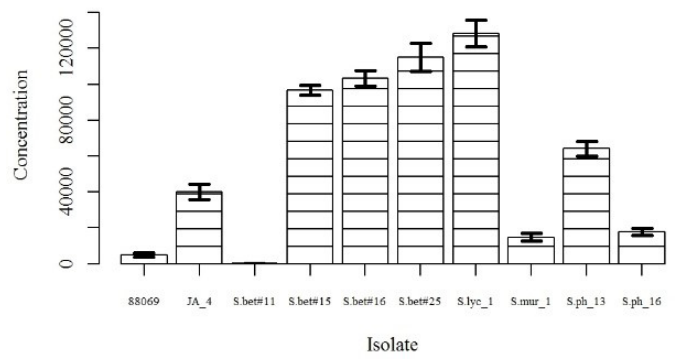

V8

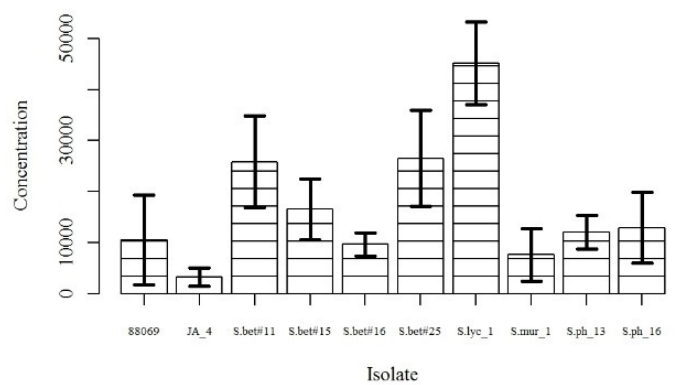

LBA

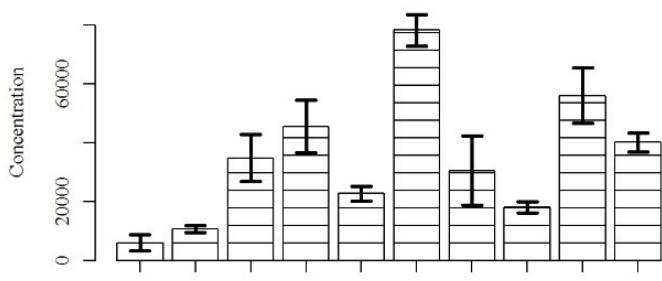

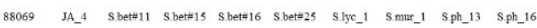

Isolate

TA

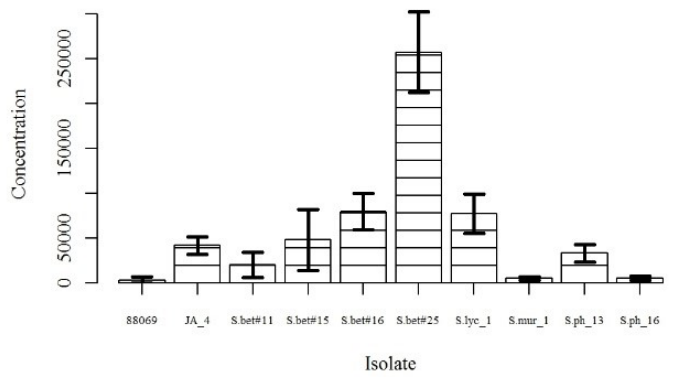

Figure 2. Mean concentration of sporangia produced by each isolate on each media evaluated after 15 days post-inoculation. Error bars represent the standard error of the mean. 


\subsection{Cardinal temperatures tests}

Cardinal temperatures tested for all isolates after 15 days on Rye A modified showed that $15^{\circ} \mathrm{C}$ was the temperature with the best growth rate for most of them with a mean of $37.98 \mathrm{~mm}$, followed by $20^{\circ} \mathrm{C}$ (mean $\left.=29.90 \mathrm{~mm}\right)$, then $25^{\circ} \mathrm{C}($ mean $=11.67 \mathrm{~mm})$ and finally $10^{\circ} \mathrm{C}($ mean $=6.06 \mathrm{~mm})$ (Table 3, Figure 3). The isolates with the best growth rate in the whole range of temperatures evaluated were Sphu\#13 from S. phureja (yellow potato) and Sbet\#15 from $S$. betaceum (tree tomato) both collected in Putumayo, Colombia. Then, Sbet\#11 and Sbet\#25 followed by tomato (S. lycopersicum), S. muricatum gathered all in Antioquia, Colombia. Finally, isolates with the smallest growth were

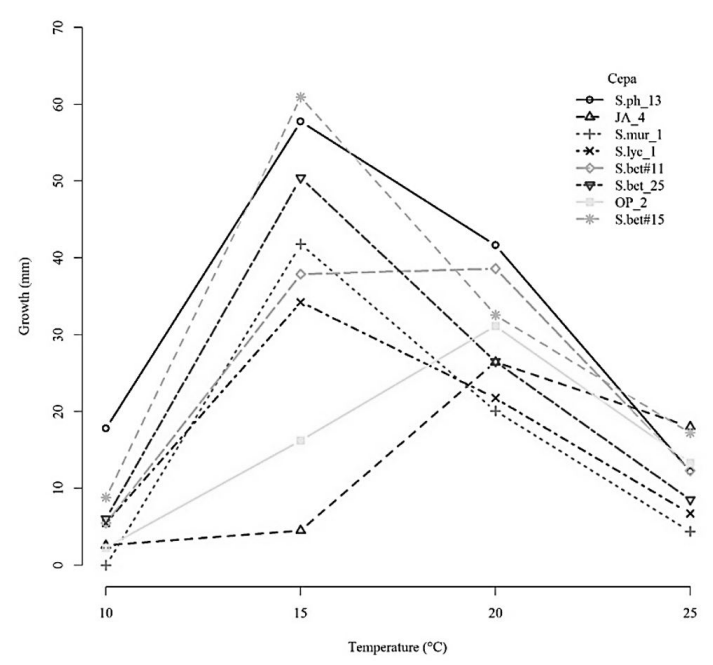

Figure 3. Growth $(\mathrm{mm})$ of each isolate measured 15 days post-inoculation at four different temperatures. Two plates per temperature were measured and the assay was repeated three times for a total of six pseudo-replicates used to calculate the mean values. isolates OP-2 and JA-4 from $S$. quitoense (lulo) collected in Antioquia and Huila, respectively. Table 3 summarizes cardinal temperatures for each isolate evaluated in this work.

\subsection{Micro-morphometric analysis}

\subsubsection{Sporangia size average}

Sporangia size were in the range from $45.01 \pm 7.17$ to $58.46 \pm 11.45 \mu \mathrm{m}$. The shortest length was measured for isolate Scar\#1 and the longest was for isolate Smur\#1 both collected in Antioquia. Width values oscillated between $28.67 \pm 3.05$ to $38.644 \pm 5.20 \mu \mathrm{m}$. Isolate Ssua\#1 was the narrowest and Sphu\#13 the widest. Microscopical structures observed are summarized in Table 4.

\subsubsection{Sporangia shape}

The most frequently observed shape for all isolates during the micro-morphometric test was naviculate. In fact, five out of the 12 isolates evaluated presented naviculate sporangia frequency above $80 \%$. The second more frequent sporangia shape was pyriform present in seven out of 12 isolates in a frequency range from 4 to $41 \%$ followed by the ellipsoid shape present in seven isolates with a frequency range from 4 to $24 \%$. For isolates 88069 from S. tuberosum, OP_2 from S. quitoense, Sbet\#11 from $S$. betaceum and Slyc\#1 from S. lycopersicum, more than three sporangia shapes were observed being naviculate and ellipsoid the most frequent. Only in 88069 the spherical shape was observed at a low frequency of $8.7 \%$.

\subsubsection{L:W ratio}

The L:W ratio varied in a range from $1.45 \mu \mathrm{m}$ for isolate Sphu\#13 of $S$. phureja to $1.98 \mu \mathrm{m}$ in Ssua\#1 of S. suaveolens (Kunth and C. D. Bouché).

\subsubsection{Type of papilla}

Semi-papillated was the most frequent type for sporangia observed during the tests. For some isolates like Smur\#1, 88069, Sphu\#13, Scar\#1 and Slyc\#1 the papilla

Table 3. Cardinal temperatures.

\begin{tabular}{|c|c|c|c|}
\hline ISOLATE & $\begin{array}{c}\text { MINIMUM } \\
\text { TEMPERATURE }\left({ }^{\circ} \mathrm{C}\right)\end{array}$ & $\begin{array}{c}\text { OPTIMAL TEMPERATURE } \\
\left({ }^{\circ} \mathrm{C}\right)\end{array}$ & $\begin{array}{c}\text { MAXIMUM } \\
\text { TEMPERATURE }\left({ }^{\circ} \mathrm{C}\right)\end{array}$ \\
\hline Sphu\#13 & $\begin{array}{c}\mathbf{1 0} \\
\text { Mean }= \pm 17.8108\end{array}$ & $\begin{array}{c}15 \\
\text { Mean }= \pm 57.7850\end{array}$ & $\begin{array}{c}\mathbf{2 0} \\
\text { Mean }= \pm 41.6750\end{array}$ \\
\hline JA_4 & $\begin{array}{c}15 \\
\text { Mean }= \pm 4.5233\end{array}$ & $\begin{array}{c}\mathbf{2 0} \\
\text { Mean }= \pm 26.45750\end{array}$ & $\begin{array}{c}\mathbf{2 5} \\
\text { Mean }= \pm 18.0223\end{array}$ \\
\hline Smur\#1 & --- & $\begin{array}{c}15 \\
\text { Mean }= \pm 41.7966\end{array}$ & $\begin{array}{c}\mathbf{2 0} \\
\text { Mean }= \pm 21.7675\end{array}$ \\
\hline Slyc\#1 & $\begin{array}{c}10 \\
\text { Mean }= \pm 5.4891\end{array}$ & $\begin{array}{c}15 \\
\text { Mean }= \pm 34.2558\end{array}$ & $\begin{array}{c}\mathbf{2 0} \\
\text { Mean }= \pm 21.7675\end{array}$ \\
\hline Sbet\#11 & $\begin{aligned} & 15 \\
\text { Mean }= & \pm 37.8958\end{aligned}$ & $\begin{array}{c}\mathbf{2 0} \\
\text { Mean }= \pm 38.6200\end{array}$ & $\begin{array}{c}\mathbf{2 5} \\
\text { Mean }= \pm 12.3233\end{array}$ \\
\hline Sbet\#25 & $\begin{array}{c}10 \\
\text { Mean }= \pm 6.0533\end{array}$ & $\begin{array}{c}15 \\
\text { Mean }=50.4375\end{array}$ & $\begin{array}{c}\mathbf{2 0} \\
\text { Mean }= \pm 26.5108\end{array}$ \\
\hline OP_2 & $\begin{array}{c}15 \\
\text { Mean }= \pm 16.2233\end{array}$ & $\begin{array}{c}\mathbf{2 0} \\
\text { Mean }= \pm 31.1550\end{array}$ & $\begin{aligned} & \mathbf{2 5} \\
\text { Mean } & \pm 13.3416\end{aligned}$ \\
\hline Sbet\#15 & $\begin{array}{c}10 \\
\text { Mean }= \pm 8.8358\end{array}$ & $\begin{array}{c}15 \\
\text { Mean }= \pm 60.9425\end{array}$ & $\begin{array}{c}\mathbf{2 0} \\
\text { Mean }= \pm 32.5650\end{array}$ \\
\hline
\end{tabular}


Table 4. Sporangia morphology.

\begin{tabular}{|c|c|c|c|}
\hline $\begin{array}{c}\text { ISOLATE } \\
\text { HOST } \\
\text { ORIGIN }\end{array}$ & $\begin{array}{l}\text { INCUBATION } \\
\text { CONDITIONS }\end{array}$ & SPORANGIA & SPORANGIOPHORE \\
\hline $\begin{array}{l}\text { Sbet\#16 S. betaceum } \\
\text { Putumayo }\end{array}$ & $\begin{array}{l}\text { Tree Tom. Agar (TA) } \\
20^{\circ} \mathrm{C}\end{array}$ & & \\
\hline $\begin{array}{l}\text { OP_2 } \\
\text { S. quitoense } \\
\text { Huila }\end{array}$ & $\begin{array}{l}\text { Tree Tom. Agar (TA) } \\
20^{\circ} \mathrm{C}\end{array}$ & & \\
\hline $\begin{array}{l}\text { Scar\#1 } \\
\text { S. caripense Antioquia }\end{array}$ & $\begin{array}{l}\text { Detached } \\
\text { Host leaves } 25^{\circ} \mathrm{C}\end{array}$ & & \\
\hline $\begin{array}{l}88069 \\
\text { S. tuberosum Holanda }\end{array}$ & $\begin{array}{l}\text { Rye A Mod. } \\
15^{\circ} \mathrm{C}\end{array}$ & & \\
\hline
\end{tabular}

was protuberant and very easy to see in most of the mature sporangia. S. betaceum isolates showed a reduced papilla or even in some cases was not observed in comparison with the semi-papillated sporangia. In isolates from $S$. quitoense the papilla was no observed in all cases although around $80 \%$ of their sporangia were classified as semi-papillated.

\subsubsection{Pedicel}

Isolate Sbet\#16 from S. betaceum from Putumayo, Colombia, was the isolate with the longest pedicel with a mean $=5.90 \mu \mathrm{m}$. The smallest pedicel was found in isolate Scar\#1 from the wild Solanum sp. collected in Antioquia with a mean $=2.90 \mu \mathrm{m}$. By geographical region, isolates from the departament of Huila exhibited the longest pedicel $($ mean $=5.66 \mu \mathrm{m})$, Putumayo was second $($ mean $=4.68 \mu \mathrm{m})$ and Antioquia was associated with the shortest pedicel with a media $=4.0333 \mu \mathrm{m}$.

\subsubsection{Caducity}

Statistical analysis showed two groups of isolates based on the caducity of their sporangia. The first group was composed by those which were mainly caduceus such as: Scar\#1, Sphu\#13, Sbet\#15, Sbet\#25, Slyc\#1, Ssua\#1 and
Smur\#1 and the second group included isolates with less frequency of caducity: JA_4, OP-2, Sbet\#11, 88069 and Sbet\#16.

\subsubsection{Hypha measurement}

The isolate with the widest hypha was Scar\#1 from $S$. caripense with a mean of $11.123 \mu \mathrm{m}$, the narrowest hypha was measured for the isolate from Solanum sp. Ssua\#1 with a mean of $5.392 \mu \mathrm{m}$.

\subsubsection{Zoospore liberation}

Zoospore counting was performed two hours after the incubation at $4{ }^{\circ} \mathrm{C}$ in darkness. No isolates were able to liberate zoospores before this time. Results obtained from the liberation of zoospores are summarized in Figure 4. S. betaceum isolates Sbet\#11, Sbet\#25 and JA_4 were the isolates with the highest concentration of zoospores released and Sphu\#13 had the lowest concentration. For isolates Sbet\#11 and Sbet\#25, zoospore release was registered at the beginning of the first time period of evaluation at $126 \mathrm{~min}$ and reached the maximum concentration between 185 and 243 minutes. 


\section{Zoospore liberation}

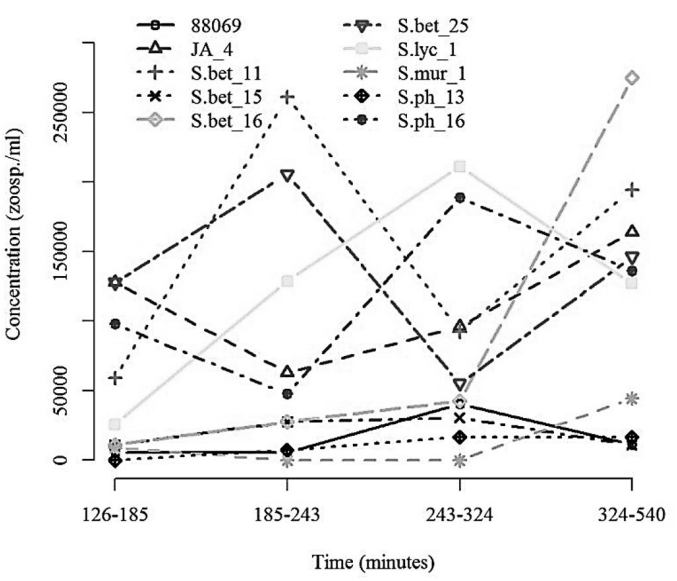

Figure 4. Zoospore liberation. Zoospore counting was performed beginning at 120 minutes after the incubation at $4{ }^{\circ} \mathrm{C}$ in darkness. No zoospores were observed before 120 minutes. The measurement was repeated twice and two measures were recorded per isolate at every time to calculate mean values.

\subsubsection{Cysts production}

Most of the isolates produced more cysts by the end of the test. After six hours of incubation, the concentration of cysts reached the maximum for half of the isolates evaluated. Sbet\#11 and Sbet\#16 reached the first peak of encystment after three hours of incubation. The isolate with the highest concentration of cysts produced was Sphu\#16 with 44.444 cysts/mL after five hours and 40 minutes of incubation, followed by isolate Slyc\#1 with 34.259 cysts $/ \mathrm{mL}$ after three to four hours of incubation. The lowest concentration of cysts was registered for isolate 88069 with 925 cysts/mL after four hours of incubation.

\section{Discussion}

\subsection{Mating type}

In the present work, no sexual structures such as antheridia, oogonioum or oospores were identified and the PCR results were consistent with the banding pattern present in the A1 mating type, indicating that all isolates tested were of the A1 mating type. In Colombia, the A1 has been reported previously as the predominant mating type in the $P$. infestans populations. Although the A2 mating type was reported in 2007 collected from the solanaceous host Physalis peruviana (L.), no further findings have been made and no other $P$. infestans symptoms or isolates have been found in this host (Danies et al., 2014; Vargas et al., 2007). Evenmore, the infection of $P$. infestans in $P$. peruviana induces responses typical of an incompatible interaction creating intriguing question about this pathosystem that requires further research. The Colombian territory has places with very difficult access for sampling mainly due to the long term war that the country has been suffering during the last 50-60 years. It is expected that during the post-conflict more regions will be surveyed to help us for a better understanding of the mating type of the $P$. infestans populations.

\subsection{Media preference test}

Hispid sparse aerial mycelia were the most common colony morphology observed during the media preference test. As was described before for $P$. infestans and the other species of Group IV (Newhook et al., 1978), the culture pattern was uniform for most isolates. Only few rosette and radiate types were registered for the isolate from S. lycopersicum Slycop\#1 growing in tree tomato agar (TA). As was described (Revelo et al., 2011; Mesa-Salgado et al., 2008), the use of a previously reported media such as Rye A favoured the ability of $P$. infestans sensu lato to grow efficiently, whereby isolates gathered from $S$. betaceum yielded better growth rates in the TA media.

Isolate 88069 is commonly used as the wild type P. infestans reference strain (Oliva et al., 2015; Whisson et al., 2005) and is characterized for its ability to grow fast and produce abundant sporangia. In this work was evident its fast ability to grow but also its diminished production of asexual structures. Reduced sporangia production in synthetic media has been reported before for a number of plant pathogens from different kingdoms such as oomycete, fungi and bacteria (Ingram and Robertson, 1965). Therefore, for host inoculation experiments where sporangia production and virulence is needed, it is important to reactivate them by growing isolates in detached leaves before the actual inoculation. Lime Bean Agar modified media (LBA) supported the growth of most of the isolates at low rate letting them to use all the resources from this media slowly, which could be convenient for prolonged storage as has been reported before (Peters et al., 1998; Goth, 1981). Lulo (S. quitoense) isolate JA_4 was unable to grow at the same rate as the other isolates evaluated in this work. It was necessary to keep this isolate under incubation conditions for 30 days to cover $75 \%$ of the plates. Even at $20^{\circ} \mathrm{C}$ in the most convenient media cultures, Rye A modified and Tree tomato agar, these isolates needed more time to grow, suggesting variability in the growth rate in the population, in some extent independent from nutrient and environmental conditions.

\subsection{Cardinal temperature}

Cardinal temperature results were different from what it was reported for Phytophthora infestans isolates by Waterhouse (1963). Even though she found the optimum was between $20-32{ }^{\circ} \mathrm{C}$, it was observed that $15^{\circ} \mathrm{C}$ was the optimal temperature for most of the isolates evaluated in this work. Likewise, the maximum range reported in the year 1963 , was between $30-36^{\circ} \mathrm{C}$, but in previous assays to define the range to be tested, none of the isolates from this collection was able to grow above $25^{\circ} \mathrm{C}$. Only the S. quitoense isolates, JA_4 and $\mathrm{OP}_{-} 2$, grew better at $20^{\circ} \mathrm{C}$ than at $15^{\circ} \mathrm{C}$. As was previously reported for this oomycete, 
optimal growth has been observed at temperatures below $20{ }^{\circ} \mathrm{C}$. Lulo crops in Colombia are frequently grown between 1600 and 2300 altitude, where temperatures oscillate between 16 to $24^{\circ} \mathrm{C}$ (Zapata and Bernal, 2012), suggesting adaptation as a possible explanation for this preference. In contrast, potato crops in Colombia are mainly cultivated between 2000 to 3000 altitude, where the range of mean temperature is from 8 to $13{ }^{\circ} \mathrm{C}$. This preference could be the reason why the $S$. phureja isolate grew faster at $15{ }^{\circ} \mathrm{C}$ in comparison with the other isolates at the same temperature.

\subsection{Morphometrics}

In the first reports about the morphology of Phytophthora spp., the shape of the sporangia was a trait that was used for the original taxonomy and thereby classification. Tucker (1931) described some of the features that were observed in most of the isolates evaluated: sporangiophores clearly differentiated from the mycelium, erect, branching compound, sympodial, with a small swelling at the base of each branch. For the tree tomato isolates the aforementioned swelling were more evident than those in the potato isolates. It was observed in this work some more variation in the sporangia shape than previously reported, being naviculate and pyriform the most common. The sporangia size range observed in this work was slightly bigger than the range defined by CAB International in $1998,45 \times 29(\max .59 \times 37) \mu \mathrm{m}$. Also, the pedicel length observed in this work was scarcely longer than the one reported by CAB International. P. infestans was not considered as part of the group of species with a distinctively large $\mathrm{L}: \mathrm{W}$ ratio $(>1.6)$, but in this work it was found that only in two isolates 88069 and Sphu\#13, this ratio was smaller than 1.6 and for the other ten isolates evaluated the L:W ratio was above 1.6. This increase in the $\mathrm{L}: \mathrm{W}$ ratio observed in most of the isolates tested in this work could be due to the effect of the growth media over the develop of their structures. There was no difference between the reports about the type of papilla for P. infestans made by Tucker (1931) since semi-papillated was the most frequent type of ending for sporangia found in this work. But some differences were observed here regarding the apparent size of the papilla. Isolates with an evident and big papilla were, Smur\#1, 88069, Sphu\#13, Scar\#1 and Slyc\#1 and the group with non-papilla or with a very small papilla were isolates collected from $S$. betaceum and $S$. quitoense. The size of the hypha measured for the isolates in the present work was between 5.4 to $11.1 \mu \mathrm{m}$, was larger than the usual size reported by other authors between 5 to $8 \mu \mathrm{m}$ (Jaramillo, 2003; Erwin and Ribeiro, 1996). Only two isolates were within this size range, Sbet\#15 and Ssuav\#1. As described, the hypha measurements could be variable and may be affected by the chemical and physical nature of the media where it grows, if the media is liquid or solid and if the mycelia is growing inside the cells of the plant host (Hartman and Huang, 1995).

Danies et al. (2014), reported that within 30 minutes of incubation at $4{ }^{\circ} \mathrm{C}$, the isolate US-24 released zoospores from more than $75 \%$ of the sporangia. However, in the present study no zoospore release was observed for all isolates tested before two hours of incubation at $4{ }^{\circ} \mathrm{C}$. In contrast with the reports the isolates evaluated here did not liberate zoospores as early as some reports mentioned it. It might be due to the long-time maintenance treatment of these isolates that one of the first trait to be affected is the zoospore delivery because under the lab conditions they do not need it at all. It seems like zoospore delivering is not an important event for the surviving of the isolate even if it is growing in a semi synthetic media with all the required nutrients and in the optimal temperature.

\section{Conclusion}

There is a relationship between the host and isolate's preferences for media culture and optimal growth temperature. In addition, the production of characteristic sporangia, sporangiophore and mycelia was related with the media type used and host from which the isolate was collected.

\section{Acknowledgements}

To Universidad Nacional de Colombia, branch Medellín, Facultad de Ciencias Agrarias, Department of Agronomical Sceinces for partial funding and support. To Colciencias, National Doctorates Program Call 2011. This work was funded by Colciencias (El patrimonio autónomo fondo nacional de financiamiento para la ciencia, la tecnología y la innovación, Francisco José de Caldas), grant project: “Análisis funcional de genes efectores de Phytophthora infestans en Solanum quitoense y especies silvestres relacionadas" code 111852128646, contract 0153-2012.

\section{References}

AFANADOR-KAFURI, L., MINZ, D., MAYMON, M. and FREEMAN, S., 2003. Characterization of Colletotrichum isolates from tamarillo, passiflora, and mango in Colombia and identification of a unique species from the genus. Phytopathology, vol. 93, no. 5, pp. 579-587. http://dx.doi.org/10.1094/PHYTO.2003.93.5.579. PMid: 18942980

CÁRDENAS, M., GRAJALES, A., SIERRA, R., ROJAS, A., GONZÁLEZ-ALMARIO, A., VARGAS, A., MARÍN, M., FERMÍN, G., LAGOS, L., GRÜNWALD, N., BERNAL, A., SALAZAR, C. and RESTREPO, S., 2011. Genetic diversity of Phytophthora infestans in the northern andean region. BMC Genetics, vol. 12, no. 1, pp. 23. http://dx.doi.org/10.1186/14712156-12-23. PMid:21303555.

DANies, G., ANTOlíneZ, C., CANTIllo, J., PEÑA, G., VARGAS, A., CÁRDENAS, M., BERNAL, A., FRY, W. and RESTREPO, S., 2014. Physalis peruviana responses to Phytophthora infestans are typical of an incompatible interaction. Canadian Journal of Plant Pathology, vol. 37, no. 1, pp. 106-117. http://dx.doi.org/10.1080/07060661.2014.975157.

ERWIN, D.C. and RIBEIRO, O.K., 1996. Phytophthora diseases worldwide. St. Paul: APS Press, The American Phytopathological Society. 
FORBES, G., MORALES, J., RESTREPO, S., PÉREZ, W., GAMBOA, S., RUIZ, R., CEDEÑO, L., FERMIN, G., ANDREU, A., ACUÑA, I. and OLIVA, R., 2013. Phytophthora infestans and Phytophthora andina on Solanaceous Hosts in South America. In: K. LAMOUR, ed. Phytophthora: a global perspective. Oxfordshire: CAB International. CABI Plant Protection Series, no. 2 , cap. 6 , pp. $48-58$.

GOSS, E.M., TABIMA, J.F., COOKE, D.E., RESTREPO, S., FRY, W.E., FORBES, G.A., FIELAND, V.J., CARDENAS, M. and GRÜNWALD, N.J., 2014. The Irish potato famine pathogen Phytophthora infestans originated in Central Mexico rather than the Andes. Proceedings of the National Academy of Sciences of the United States of America, vol. 111, no. 24, pp. 8791-8796. http://dx.doi.org/10.1073/pnas.1401884111. PMid:24889615.

GOTH, R.W., 1981. An efficient technique for prolonged storage of Phytophthora infestans. American Potato Journal, vol. 58, no. 5, pp. 257-260. http://dx.doi.org/10.1007/BF02853907.

GRÜNWALD, N.J. and FLIER, W.G., 2005. The biology of Phytophthora infestans at its center of origin. Annual Review of Phytopathology, vol. 43, no. 1, pp. 171-190. http://dx.doi. org/10.1146/annurev.phyto.43.040204.135906. PMid:16078881.

GUTIÉRREZ, J.A., 2009. La estadística estratégica del sector agropecuario en Colombia: un nuevo modelo de oferta. Revista de Información Básica, vol. 3, no. 2, pp. 3.

HARTMAN, G.L. and HUANG, Y.H., 1995. Characteristics of Phytophthora infestans isolates and development of late blight on tomato in Taiwan. Plant Disease, vol. 79, no. 8, pp. 849-852. http://dx.doi.org/10.1094/PD-79-0849.

INGRAM, D.S. and ROBERTSON, N.F., 1965. Interaction between Phytophthora infestans and tissue cultures of Solanum tuberosum. Journal of General Microbiology, vol. 40, no. 3, pp. 431-437. http://dx.doi.org/10.1099/00221287-40-3-431. PMid:5864894.

JARAMILLO, S., 2003. Monografia sobre Phytophthora infestans (Mont) de Bary. Medellín: Universidad Nacional de Colombia.

JUDELSON, H.S., 1996. Genetic and physical variability at the mating type locus of the oomycete P. infestans. Genetics, vol. 144, no. 3, pp. 1005-1013. PMid:8913745.

LAMOUR, K.H., 2013. Phytophthora: a global perspective. Oxfordshire: CABI. http://dx.doi.org/10.1079/9781780640938.0000.

MARIETTE, N., ANDRODIAS, A., MABON, R., CORBIÈRE, R., MARQUER, B., MONTARRY, J. and ANDRIVON, D., 2016. Local adaptation to temperature in populations and clonal lineages of the irish potato famine pathogen Phytophthora infestans. Ecology and Evolution, vol. 6, no. 17, pp. 6320-6331. http://dx.doi.org/10.1002/ece3.2282. PMid:27648246.

MESA SALGADO, V.M., FERNANDA MIDEROS, M., JARAMILLO-VILLEGAS, S., MIGUEL COTES-TORRES, J., LAGOS MORA, L.E., PAOLA PINEDA, R. and MARÍN MONTOYA, M., 2008. Variabilidad genética de aislamientos de Phytophthora infestans procedentes del suroeste de Colombia. Revista Iberoamericana de Micologia, vol. 57, no. 4, pp. 167-172. http://dx.doi.org/10.1016/S1130-1406(08)70039-1. PMid:18785787.

NEWHOOK, F.J., WATERHOUSE, G.M. and STAMPS, D.J., 1978. Tabular key to the species of Phytophthora de Bary. Kew: Commonwealth Mycological Institute. Mycological Papers, no. 143.
OLIVA, R.F., CANO, L.M., RAFFAELE, S., WIN, J., BOZKURT, T.O., BELHAJ, K., OH, S.K., THINES, M. and KAMOUN, S.A., 2015. Recent expansion of the RXLR effector gene Avrblb2 is maintained in global populations of Phytophthora infestans indicating different contributions to virulence. Molecular PlantMicrobe Interactions, vol. 28, no. 8, pp. 901-912. http://dx.doi. org/10.1094/MPMI-12-14-0393-R. PMid:25894205.

PARDO-DE LA HOZ, C.J., CALDERÓN, C., RINCÓN, A., CÁRDENAS, M., DANIES, G., LÓPEZ-KLEINE, L., RESTREPO, S. and JIMÉNEZ, P., 2016. Species from the Colletotrichum acutatum, Colletotrichum boninense and Colletotrichum gloeosporioides species complexes associated with tree tomato and mango crops in Colombia. Plant Pathology, vol. 65, no. 2, pp. 227-237. http://dx.doi.org/10.1111/ppa.12410.

PÉREZ, W.G., GAMBOA, J.S., FALCON, Y.V., COCA, M., RAYMUNDO, R.M. and NELSON, R.J., 2001. Genetic structure of peruvian populations of Phytophthora infestans. Phytopathology, vol. 91, no. 10, pp. 956-965. http://dx.doi. org/10.1094/PHYTO.2001.91.10.956. PMid:18944122.

PETERS, R.D., PLATT, H.W. and HALL, R., 1998. Long-term survival of Phytophthora infestans in liquid media prepared from autoclaved seeds. Canadian Journal of Plant Pathology, vol. 20, no. 2, pp. 165-170. http://dx.doi.org/10.1080/07060669809500422.

REVELO, E., DORADO, G., LAGOS, L.E. and BURBANOFIGUEROA, O., 2011. Foliar virulence of isolates of Phytophthora infestans sensu lato on detached leaves of two Solanum betaceum cultivars. Tropical Plant Pathology, vol. 36, no. 6, pp. 367-373. http://dx.doi.org/10.1590/S1982-56762011000600005.

SILVA, B., JARAMILLO, S. and MARÍN, M., 2009. Caracterización genética de aislamientos de Phytophthora infestans en las zonas productoras de papa de los departamentos de Antioquia, Boyacá, Cundinamarca y Norte de Santander (Colombia). Actualidades Biologicas, vol. 31, no. 90, pp. 5-20.

TUCKER, C. M., 1931. Taxonomy of the genus Phytophthora De Bary. Columbia: University of Missouri, Agricultural Experiment Station. Research Bulletin, no. 153, 208 p.

VARGAS, A.M., CORREA, A., LOZANO, D., GONZÁLEZ, A., BERNAL, A., RESTREPO, S. and JIMÉNEZ, P., 2007. First report of late blight caused by Phytophthora infestans on cape gooseberry (Physalis peruviana) in Colombia. Plant Disease, vol. 91, no. 4, pp. 464. http://dx.doi.org/10.1094/PDIS-91-4-0464B. PMid:30781206.

WATERHOUSE, G.M., 1963. Key to species of Phytophthora de Bary. Mycological Papers, vol. 92, pp. 1-22.

WHISSON, S.C., AVROVA, A.O., LAVROVA, O. and PRITCHARD, L., 2005. Families of short interspersed elements in the genome of the oomycete plant pathogen, Phytophthora infestans. Fungal Genetics and Biology, vol. 42, no. 4, pp. 351365. http://dx.doi.org/10.1016/j.fgb.2005.01.004. PMid:15749054.

ZAPATA, J.L. and BERNAL, J.A., 2012. Caracterización de razas fisiológicas de Phytophthora infestans (Mont.) de Bary en lulo (Solanum quitoense Lam.). Corpoica Ciencia y Tecnología Agropecuaria, vol. 13, no. 1, pp. 13-20. http://dx.doi.org/10.21930/ rcta.vol13_num1_art:235. 